\title{
Idiopathic haemochromatosis and HLA antigens in Italy: Is A3 Bw35 HLA haplotype a marker for idiopathic haemochromatosis gene in north east regions?
}

\author{
A PIPERNO, S FARGION, N PANAIOTOPOUlOS,* E DEL NINNO, MT TADDEI, \\ G FIORELLI \\ Istituto di Clinica Medica III, Cattedra di Patologia Medica IV, Università di Milano, Italy, and the *Istituto \\ Ortopedico G Pini, Sezione Immunotrasfusionale, Milan, Italy
}

SUMMARY Thirty two unrelated Italian subjects with idiopathic haemochromatosis were studied. HLA-A 3 was present in 26 of them $(81 \% v 22 \%$ in controls; $p<0.001)$ and HLA B7 in eight $(28 \%$ $v 9 \% ; \mathrm{p}<0.01)$. There was no important association between idiopathic haemochromatosis and HLA B14. Subdividing the patients on the basis of their regional origin a noticeably higher prevalence of HLA Bw35 in patients with idiopathic haemochromatosis from north eastern Italy was found than in those from Lombardy, or in the controls; there were no differences in the incidence of HLA A3 and B7 between patients with idiopathic haemochromatosis from different areas.

A high prevalence of A3, Bw35, and A3, B7 haplotypes was found in our patients with idiopathic haemochromatosis. A3, Bw35 could be the haplotype most commonly linked to the idiopathic haemochromatosis gene in north eastern Italy.

Several studies have indicated a close association between the haemochromatosis gene and the HLA complex. ${ }^{1-3}$ A high prevalence of HLA-A3 and in some instances, of HLA-B7 and HLA-B14 antigens has been found in unrelated subjects with idiopathic haemochromatosis from different countries. ${ }^{1-3}$

Few data about HLA distribution in patients with idiopathic haemochromatosis from Italy are available. In nine subjects we previously observed a strong association with the HLA-A3 antigen but not with the HLA-B7 or HLA-B14 antigens. ${ }^{4}$ Zacchi $e t a l^{5}$ found an association between the idiopathic haemochromatosis gene and A3, Bw35 haplotype in two families from north eastern Italy.

This study aimed to define the prevalence of HLA antigens in 32 unrelated Italian subjects with idiopathic haemochromatosis and to find the haplotype most often associated to the idiopathic haemochromatosis gene. Moreover, the regional origin of these patients was assessed to confirm a suspected uneven distribution of some HLA antigens and haplotypes among the different areas of the country.

Accepted for publication 8 October 1985

\section{Material and methods}

Thirty two unrelated Italian subjects (29 men and three women) aged from 22 to 63 years were studied. Idiopathic haemochromatosis was diagnosed on clinical, biochemical, and histological grounds. ${ }^{6}$ Two of the patients also had heterozygous $\beta$ thalassaemia.

The patients' regional origins within Italy were ascertained by genealogical research up to three previous generations. In all the cases considered the patients' ascendents had the same regional origin.

We ascertained the prevalence of HLA antigens in a group of 128 Italian healthy blood donors for comparison. Twenty two families with haemochromatosis were HLA typed, giving the genotype of 21 unrelated probands and 41 haplotypes.

The expected prevalence of some haplotypes was calculated on the basis of their individual alleles previously reported by Piazza et al in 2819 healthy Italian subjects (Sardinia excluded). ${ }^{7}$

Serum iron concentrations and total iron binding capacity were performed using standard techniques. Serum ferritin concentration was measured by radioimmunoassay (Lisophase, Lepetit). Sections of liver biopsy were stained with hematoxylin and eosin and 
Table 1 Clinical, biochemical, and histological data of unrelated Italian subjects with idiopathic haemocromatosis

\begin{tabular}{|c|c|c|c|c|c|c|c|c|}
\hline \multirow{2}{*}{$\begin{array}{l}\text { Case } \\
\text { no }\end{array}$} & \multirow[t]{2}{*}{ Sex } & \multirow[t]{2}{*}{ Age } & \multirow{2}{*}{$\begin{array}{l}\text { Clinical }^{*} \\
\text { signs }\end{array}$} & \multirow{2}{*}{$\begin{array}{l}\text { Serum iron } \\
\text { ( } \mu \mathrm{mol} / l)\end{array}$} & \multirow{2}{*}{$\begin{array}{l}\text { Transferrin } \\
\text { saturation } \\
(\%)\end{array}$} & \multirow{2}{*}{$\begin{array}{l}\text { Serum } \\
\text { ferritin } \\
(\mathrm{ng} / \mathrm{ml})\end{array}$} & \multicolumn{2}{|c|}{ Liver biopsy } \\
\hline & & & & & & & $\begin{array}{l}\text { Iron } \\
\text { grade }\end{array}$ & Histology \\
\hline $\begin{array}{l}1 \\
2 \\
3 \\
4 \\
5 \\
6 \\
7 \\
8 \\
9 \\
10 \\
11 \\
12 \\
13 \\
14 \\
15 \\
16 \\
17 \\
18 \\
19 \\
20 \\
21 \\
22 \\
23 \\
24 \\
25 \\
26 \\
27 \\
28 \\
29 \\
30 \\
31 \\
32\end{array}$ & $\begin{array}{l}\mathbf{M} \\
\mathbf{M} \\
\mathbf{M} \\
\mathbf{M} \\
\mathbf{M} \\
\mathbf{M} \\
\mathbf{M} \\
\mathbf{M} \\
\mathbf{M} \\
\mathbf{F} \\
\mathbf{M} \\
\mathbf{M} \\
\mathbf{M} \\
\mathbf{M} \\
\mathbf{M} \\
\mathbf{M} \\
\mathbf{M} \\
\mathbf{F} \\
\mathbf{F} \\
\mathbf{M} \\
\mathbf{M} \\
\mathbf{M} \\
\mathbf{M} \\
\mathbf{M} \\
\mathbf{M} \\
\mathbf{M} \\
\mathbf{M} \\
\mathbf{M} \\
\mathbf{M} \\
\mathbf{M} \\
\mathbf{M} \\
\mathbf{M}\end{array}$ & $\begin{array}{l}56 \\
43 \\
50 \\
48 \\
22 \\
36 \\
42 \\
50 \\
56 \\
42 \\
50 \\
63 \\
43 \\
37 \\
50 \\
26 \\
63 \\
45 \\
53 \\
50 \\
52 \\
35 \\
37 \\
54 \\
56 \\
62 \\
59 \\
36 \\
52 \\
64 \\
48 \\
36\end{array}$ & $\begin{array}{l}\text { H, P, D, C, G } \\
\text { H, P, D } \\
\text { H, P, C, G, A } \\
\text { H, P, D, G } \\
\text { P } \\
\text { H, P, D, A } \\
\text { H, A } \\
\text { H, P, D, G, A } \\
\text { H, P, D, G } \\
\text { H, P, G, A } \\
\text { H, P, G } \\
\text { H, D, G, A } \\
\text { H, P, G, A } \\
\text { H, P } \\
\text { H, P, A } \\
\text { H } \\
\text { H, P, D, G } \\
\text { A P, D, A } \\
\text { H, P, } \\
\text { H, P } \\
\text { H, P, D, G } \\
\text { H, P, C } \\
\text { H, P, D, C, G, A } \\
\text { H, P } \\
\text { H, G } \\
\text { H, P, D, A } \\
\text { H, P } \\
\text { P } \\
\text { H } \\
\text { H, P, A } \\
\text { H, P } \\
\text { H, P, G, A }\end{array}$ & $\begin{array}{l}31 \cdot 3 \\
35 \cdot 8 \\
33 \cdot 3 \\
31 \cdot 3 \\
26 \cdot 8 \\
36 \cdot 5 \\
27 \cdot 5 \\
32 \cdot 7 \\
32 \cdot 8 \\
24 \cdot 7 \\
39 \cdot 7 \\
13 \cdot 6 \\
34 \\
49 \cdot 2 \\
30 \\
37 \cdot 6 \\
39 \cdot 6 \\
26 \cdot 5 \\
32 \cdot 4 \\
27 \cdot 4 \\
33 \cdot 8 \\
30 \cdot 8 \\
37 \cdot 4 \\
31 \cdot 9 \\
53 \cdot 1 \\
30 \cdot 5 \\
30 \\
39 \cdot 8 \\
43 \cdot 5 \\
52 \cdot 5 \\
28 \\
28\end{array}$ & $\begin{array}{l}87 \\
85 \\
88 \\
83 \\
71 \\
78 \\
52 \\
70 \\
55 \\
78 \\
86 \\
44 \\
93 \\
93 \\
74 \\
80 \\
65 \\
61 \\
96 \\
55 \\
81 \\
68 \\
89 \\
86 \\
92 \\
77 \\
77 \\
85 \\
63 \\
80 \\
\\
78\end{array}$ & $\begin{array}{r}2900 \\
4000 \\
2800 \\
4600 \\
760 \\
4600 \\
300 \\
3000 \\
1400 \\
2600 \\
2600 \\
2800 \\
4000 \\
2600 \\
1520 \\
600 \\
1500 \\
420 \\
4000 \\
1160 \\
1300 \\
6000 \\
3360 \\
3200 \\
5200 \\
1700 \\
3520 \\
540 \\
920 \\
1040 \\
2000 \\
1840\end{array}$ & $\begin{array}{l}3 \\
4 \\
4 \\
4 \\
4 \\
4 \\
4 \\
4 \\
4 \\
3 \\
4 \\
3 \\
4 \\
3 \\
3 \\
4 \\
4 \\
4 \\
4 \\
3 \\
4 \\
3 \\
4\end{array}$ & $\begin{array}{l}\text { Cirrhosis } \\
\text { Fibrosis } \\
\text { Cirrhosis } \\
\text { Cirrhosis } \\
\text { Normal } \\
\text { Fibrosis } \\
\text { Cirrhosis } \\
\text { Cirrhosis } \\
\text { Cirrhosis } \\
\text { Cirrhosis } \\
\text { Cirrhosis } \\
\text { Cirrhosis } \\
\text { Cirrhosis } \\
\text { Cirrhosis } \\
\text { Normal } \\
\text { Cirrhosis } \\
\text { Normal } \\
\text { Cirrhosis } \\
\text { Cirrhosis } \\
\text { Cirrhosis } \\
\text { Cirrhosis } \\
\text { Cirrhosis } \\
\text { Cirrhosis } \\
\text { Fibrosis and chronic hepatitis } \\
\text { Cirrhosis } \\
\text { Cirrhosis } \\
\text { Fibrosis } \\
\text { Fibrosis and chronic hepatitis } \\
\text { Cirrhosis } \\
\text { Cirrhosis }\end{array}$ \\
\hline
\end{tabular}

${ }^{*} \mathrm{H}=$ hepatomegaly; $\mathrm{P}=$ pigmentation; $\mathrm{D}=$ diabetes; $\mathrm{C}=$ cardiopathy; $\mathbf{G}=$ hypogonadism; $\mathrm{A}$ = arthropathy

$\dagger \mathrm{N}=$ normal; $\mathrm{F}=$ fibrosis; $\mathrm{C}=$ cirrhosis; $\mathrm{CH}=$ chronic hepatitis.

Perls's Prussian blue for iron for histological evaluation. The amount of stainable iron in hepatocytes was graded 0 to $4 .^{8}$

HLA-A and HLA-B locus antigens were identified with the National Institute of Health (USA) standard microlymphocytoxicity test using 120 highly selected antisera provided by GCTT (Italian Cooperative Group for Tissue Typing) and by the University of California of Los Angeles, United States. For some of the antigens, such as A3 and A11, several antisera (respectively, 6 and 5), were used to rule out the possibility of any cross reactions. ${ }^{9}$

\section{Results}

Table 1 shows the data for iron concentrations and the histological and clinical findings of each patient. At least one clinical manifestation of idiopathic

Table 2 Prevalence of $H L A-A$ and $H L A-B$ antigens in subjects with idiopathic haemochromatosis and in controls (figures in parentheses are numbers \%)

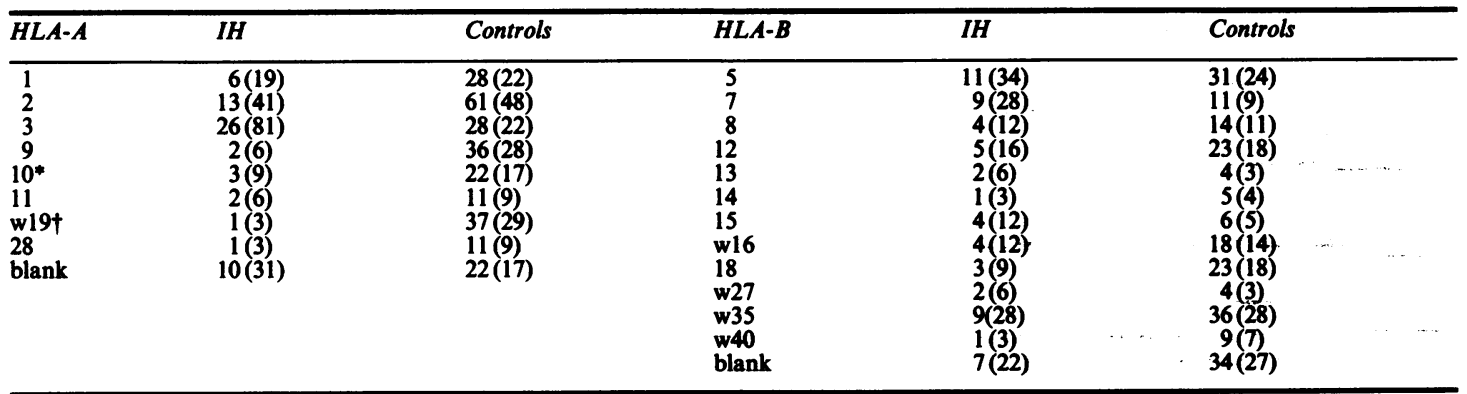

*Includes A25 and A26.

†Includes Aw29, Aw30-31, and Aw32.

IH = Idiopathic haemochromatosis. 
Table 3 Prevalence of HLA-A and HLA-B antigens in subjects with idiopathic haemochromatosis from Lombardy and Veneto-Friuli regions (figures in parentheses are numbers \%)

\begin{tabular}{|c|c|c|c|c|c|}
\hline \multirow[t]{2}{*}{ HLA-A } & \multicolumn{2}{|l|}{ Region } & \multirow[t]{2}{*}{$H L A-B$} & \multicolumn{2}{|l|}{ Region } \\
\hline & Lombardy & $\overline{V e n e t o-F r i u l i}$ & & Lombardy & Veneto-Friuli \\
\hline $\begin{array}{l}1 \\
2 \\
3 \\
9 \\
10^{*} \\
11 \\
\text { w19+ } \\
28 \\
\text { blank }\end{array}$ & $\begin{array}{c}5(25) \\
9(45) \\
15(75) \\
2(10) \\
2(10) \\
1(5) \\
1(5) \\
6(30)\end{array}$ & $\begin{array}{l}1(12.5) \\
2(25) \\
7(87.5) \\
1(12.5) \\
1(12.5) \\
1(12.5) \\
3(37.5)\end{array}$ & $\begin{array}{l}5 \\
7 \\
8 \\
12 \\
13 \\
14 \\
15 \\
\text { w16 } \\
17 \\
18 \\
\text { w27 } \\
\text { w35 } \\
\text { blank }\end{array}$ & $\begin{array}{l}6(30) \\
6(30) \\
4(20) \\
4(20) \\
1(5) \\
2(10) \\
4(20) \\
\\
2(10) \\
2(10) \\
3(15) \\
5(25)\end{array}$ & $\begin{array}{l}1(12 \cdot 5) \\
2(25) \\
1(12 \cdot 5) \\
1(12 \cdot 5) \\
1(12 \cdot 5) \\
1(12 \cdot 5)\end{array}$ \\
\hline
\end{tabular}

*Includes A25 and A26.

†Includes Aw29, Aw30-31, and Aw32.

haemochromatosis, increased transferrin saturation or serum ferritin, or both clinical and biochemical abnormalities (generally both), was present in all the patients. Cirrhosis was present in $21(70 \%)$, fibrosis in three $(10 \%)$, and normal findings in three $(10 \%)$; in two cases that were both negative for hepatitis B virus markers fibrosis was associated with findings of chronic hepatitis.

The prevalence of HLA antigens reported in Table 2 indicates that HLA A3 and B7 are significantly commoner in patients with haemochromatosis as opposed to controls $(81 \%$ v $22 \%, p<0.001$, and $28 \%$ v $9 \%, \mathrm{p}<0.01$, respectively).

Twenty patients came from Lombardy and eight from Veneto-Friuli. The remaining four patients came from various regions.

Table 3 reports the prevalence of HLA antigens in patients with idiopathic haemochromatosis from Lombardy and Veneto-Friuli. Although the prevalence HLA-A3 and B7 is similar, there is a noticeably higher prevalence of HLA-Bw35 in subjects with idiopathic haemochromatosis from Veneto-Friuli than in those from Lombardy and in controls.

Table 4 shows the haplotypes most commonly observed in our patients. The prevalence of A3, Bw35;

Table 4 Most common HLA haplotypes in patients with idiopathic haemochromatosis and their expected prevalence in healthy subjects

\begin{tabular}{lllll}
\hline Haplotypes & IH & $\begin{array}{l}\text { Observed } \\
\text { prevalence } \\
\text { (21 cases) }\end{array}$ & Normal & $\begin{array}{l}\text { Expected } \\
\text { prevalence } \\
(2819 \text { cases }) \dagger\end{array}$ \\
\hline A3 Bw35 & $9 *$ & 0.219 & 108 & 0.0192 \\
A3 B7 & 4 & 0.098 & 42 & 0.0074 \\
A3 B5 & 4 & 0.098 & 76 & 0.0135 \\
A2 B15 & 2 & 0.048 & 58 & 0.0103 \\
\hline
\end{tabular}

*Eight from North East Italy. +Piazza et al 7.

IH = Idiopathic haemochromatosis.
A3, B7; and A3, B5 was considerably higher than that expected by random association. Eight of the nine A3, Bw35 haplotypes were identified in patients from north eastern Italy (Veneto and Friuli regions).

\section{Discussion}

These results confirm that in Italy HLA-A3 is also closely associated with the idiopathic haemochromatosis gene. The prevalence of HLA-B7 was also higher than that of controls, although it was slightly lower than that reported from other countries. ${ }^{23}$

Subdividing our patients on the basis of their regional origin, we found a much higher prevalence of HLA-Bw35 in patients with idiopathic haemochromatosis from north eastern Italy (VenetoFriuli) than in those from Lombardy or in controls. As the prevalence of HLA-Bw35 in Veneto-Friuli was comparable with that of other Italian regions ${ }^{7}$ we suppose that its increase in patients with idiopathic haemochromatosis from north eastern Italy was related to a close association between this antigen and the idiopathic haemochromatosis gene in this area. The association between HLA-Bw35 and idiopathic haemochromatosis is not completely new: le Mignon et $a l^{9}$ found an increased prevalence of HLA A11, Bw35 haplotype that approached the threshold of significance; Zacchi et al $^{5}$ described two families, both originating from north eastern Italy, in whom the idiopathic haemochromatosis gene was associated with the A3, Bw35 haplotype. In our six patients from Veneto and Friuli who had Bw 35 only one was not positive for A3; studies of families show that in all the others Bw35 was linked to A3 and that three of the patients were even homozygous for this haplotype, suggesting a considerable imbalance in the association between $\mathrm{A} 3$ and Bw35 in this population with idio- 
pathic haemochromatosis. In fact, the prevalence of this haplotype in our patients with idiopathic haemochromatosis was much higher than that expected by chance, although the absence of a comparable control group for HLA haplotypes does not allow definitive conclusions to be drawn.

Supported by the findings of Zacchi et al, ${ }^{5}$ our data suggest that HLA Bw35 could be a major HLA-B antigen linked to idiopathic haemochromatosis in north eastern Italy and also that A3, Bw35 could be the most common haplotype marking the haemochromatosis gene in this area. On the other hand, HLA B7 and the A3, B7 haplotype seem to be more homogeneously distributed through the whole of northern Italy. Different migratory routes could explain the uneven geographical distribution of these haplotypes. Further studies are needed to confirm the prevalence of HLA Bw35 and A3, Bw35 haplotype in north eastern Italy and to define whether other haplotypes are present in patients with idiopathic haemochromatosis originating from other areas of Italy.

\section{References}

${ }^{1}$ Simon M, Bourel M, Fauchet R, Genetet B. Association of HLA-
A3 and HLA-B14 antigens with idiopathic haemochromatosis. Gut 1976;17:332-4.

${ }^{2}$ Simon M, Fauchet R, Genetet B, Bourel M. The genetics of haemochromatosis. In: Stenberg AG, Bearn A, Motulsky AG, Childs B, eds. Progress in medical genetics. Philadelphia: WB Saunders, 1980:135-68.

${ }^{3}$ Doran TJ, Bashir HV, Trejaut J, et al. Idiopathic haemochromatosis in the Australian population: HLA linkage and recessivity. Hum Immunol 1981;2:191-200.

${ }^{4}$ Panaiotopoulos N, Farè M, Gaboardi D, et al. In: Advances in red cell biology. Florence: Menarini International Foundation, 1981: 78.

${ }^{5}$ Zacchi T, Marin MG, Galli G, Tiribelli C. HLA antigens and idiopathic haemochromatosis in north-east Italy: a familial study. Italian Journal of Gastroenterology 1982;14:205-7.

${ }^{6}$ Simon M, Hespel JP, Brissot P, Fauchet R, et al. Les hémochromatoses. Ann Med Interne 1981;136:413-33.

${ }^{7}$ Piazza A, Olivetti E, Carbonara O, et al. The distribution of some genetic polymorphisms in Italy. Ric Clin Lab 1982;2:102-8.

${ }^{8}$ Sheuer PJ, Williams R, Muir AR. Hepatic pathology in relatives of patients with Hemochromatosis. Journal of Pathology and Bacteriology 1962;84:53-64.

${ }^{9}$ Raffoux C, Straff F. Joint report: A11. In: Terasaki PI, ed. Eighth histocompatibility testings 1980. Los Angeles: UCLA Tissue Typing Laboratory, 1980: 299-301.

${ }^{10}$ Le Mignon L, Simon M, Fauchet R, et al. An HLA-A1l association with the hemochromatosis allele? Clin Genet 1983;24:171-6.

Requests for reprints to: Dr A Piperno, Istituto di Clinica Medica III, Via Pace 9, 20122 Milano, Italy. 